\title{
PROSES TERMAL DAN PENDUGAAN UMUR SIMPAN NASI GORENG DALAM KEMASAN RETORT POUCH
}

\section{(THERMAL PROCESSOF FRIED RICE IN RETORT POUCH PACKAGING AND ITS SHELF LIFE PREDICTION)}

\author{
Muhamad Kurniadi, Annisa Kusumaningrum, Asep Nurhikmat, Agus Susanto \\ Balai Penelitian Teknologi Bahan Alam LIPI, Gunungkidul, Yogyakarta, Indonesia \\ E-mail: hm_kur@yahoo.com
}

Diterima : 05-09-2018

Direvisi : 19-10-2018

Disetujui : 04-12-2018

\begin{abstract}
ABSTRAK
Penelitian mengenai proses termal dan pendugaan umur simpan nasi goreng dalam kemasan retort pouch telah dilakukan. Tujuan penelitian yaitu melakukan optimasi sterilisasi dan pendugaan umur simpan nasi goreng dalam retort pouch. Optimasi sterilisasi dilakukan pada suhu $110^{\circ} \mathrm{C}$ dan $121^{\circ} \mathrm{C}$ dengan waktu 15 menit dan 20 menit, menggunakan parameter uji Angka Kecukupan Panas (Fo) dan uji Angka Lempeng Total (ALT). Pendugaan umur simpan menggunakan teknik Accelerated Shelf-life Test (ASLT) model Arrhenius melalui pendekatan penurunan mutu angka ketengikan thiobarbituric acid (TBA). Penyimpanan sampel pada variasi suhu 27,35 dan $55^{\circ} \mathrm{C}$, diuji setiap 7 hari selama 35 hari.Hasil penelitian menunjukkan bahwa proses sterilisasi retort pouch yang terbaik yaitu pada suhu $121^{\circ} \mathrm{C}$ selama 20 menit. Hasil ALT yaitu 0,4 × 103 cfu/ml dan Angka Kecukupan Panas Fo 11,88 menit. Perkiraan umur simpan nasi goreng dalam retort pouch adalah 8,25 bulan.
\end{abstract}

Kata kunci : Nasi goreng, umur simpan, retort pouch, model Arrhenius, Fo, TBA.

\section{ABSTRACT}

Research about thermal process of fried rice in retort pouch packaging and its shelf life prediction were conducted. The aim of this study were thermal process optimization and predicted shelf life of fried rice in retort pouch packaging. Thermal process was done in temperature of $110{ }^{\circ} \mathrm{C}$ and $121^{\circ} \mathrm{C}$ during 15 minutesand 20 minutes using parameters i.e. lethality value (Fo) and Total Plate count (TPC). Shelf life prediction used Accelerated Shelf-life Test (ASLT) model Arrhenius through decresed of rancidity approach. The samples were storaged in various temperature 27,35 dan $55^{\circ} \mathrm{C}$ and analyzed once a week for 35 days. The results showed that the best of thermal process in $121^{\circ} \mathrm{C}$ for 20 minutes. The Result of TPC value was $0,4 \times 10^{3} \mathrm{cfu} / \mathrm{ml}$ and lethality value 11.88 minutes. Shelf life prediction of fried rice in retort pouch packaging was 8.25 months.

Keywords. Fried rice, shelf life, retort pouch, Arrhenius model, Fo, TBA

\section{PENDAHULUAN}

$\mathrm{P}$

roses termal merupakan salah satu proses dalam pengolahan pangan yang berfungsi menginaktivasi mikroba dalam bahan makanan untuk menjamin keamanan produk pangan tersebut. Proses pemanasan bahan pangan biasanya menggunakan sterilisasi komersial (suhu $121,1^{\circ} \mathrm{C}$ ) dimana proses ini lebih optimal dari pada pasteurisasi (suhu $80^{\circ} \mathrm{C}$ ). Pada sterilisasi komersial menyebabkan kematian mikroba pathogen. Produk yang dihasilkan pada sterilisasi komersial memiliki umur simpan yang lebih lama dan tidak perlu disimpan dalam suhu dingin (Lewis and Heppell, 2000).

Retort pouch adalah kemasan fleksibel berbentuk kantong yang digunakan untuk mengemas produk pangan yang siap santap (Murniyati, 2009), retort pouch terbuat dari 
laminasi alumunium foil dan polimer tahan terhadap proses sterilisasi dan dapat disimpan dalam waktu lama pada suhu kamar. Keuntungan penggunaan retort pouch antara lain sifat pouch yang elastis, efisiensi penyimpanan dan pengangkutan, dan mampu mempertahankan kualitas dari produk yang dikemas (Shihab et al., 2013). Bindu et.al.(2004) melaporkan pengolahan kerang dalam retort pouch yang disterilisasi selama 35 menit menghasilkan produk yang masih baik setelah disimpan sampai satu tahun dalam suhu kamar. Proses termal yang tidak sesuai dapat menyebabkan kemasan retort pouch pecah atau terbuka.

Nasi goreng adalah nasi yang diolah dengan cara digoreng dengan menggunakan sedikit minyak (Hidayati dan Ismawati, 2014).Pengolahan makanan dengan cara menggoreng dapat menyebabkan penurunan fisikokimia yang juga dapat mempengaruhi kestabilan produk selama penyimpanan. Adanya oksidasi lemak merupakan reaksi penurunan yang umum terjadi karena adanya kontak antara minyak goreng dengan makanan yang digoreng (Lim and Han, 2016).Pengemasan nasi goreng dalam retort pouch adalah salah satu diversifikasi sebagai makanan siap saji (Ready to Eat). Aspek penting yang perlu diperhatikan dalam pengolahan nasi goring kemasan retort pouch adalah sterilisasi. Tujuan sterilisasi yaitu memperpanjang keawetan produk pangan dengan membunuh mikroba pembusuk dan patogen, memperbaiki mutu sensori, melunakkan produk, meningkatkan daya cerna protein dan karbohidrat, dan menghancurkan komponen-komponen yang tidak diperlukan. Proses termal yang berlebihan dapat merusak komponen gizi dan menurunkan mutu sensori produk (Yuswita, 2014). Adapun faktor utama yang harus diperhatikan dalam proses sterilisasi adalah angka kecukupan panas atau nilai $F o$. Nilai $F o$ adalah jumlah waktu (dalam menit) pada suhu tertentu yang diperlukan untuk menghancurkan semua mikroba. Resistensi panas mikroorganisme dinyatakan sebagai waktu kematian thermal atau Thermal Death Time (TDT) yaitu waktu yang dibutuhkan untuk membunuh sejumlah sel atau spora tertentu pada kondisi fisik tertentu. TDT pada suhu $121^{\circ} \mathrm{C}$ telah digunakan sebagai referensi sterilisasi dan dinyatakan sebagai Fo. Untuk Clostridium botulinum nilai Fo-nya 2,45 - 2,8 menit, ( Lewis,2000 ).

Masalahnya pada pengolahan nasi goreng retort pouch ini adalah berapa suhu dan waktu sterilisasi yang optimum serta berapa angka kecukupan panas sterilisasinya (Nilai Fo) agar didapatkan produk nasi goreng dalam kemasan retort pouch tetap baik dan mempunyai umur simpan yang lama.

Umur simpan ditentukan berdasarkan faktor yang paling berpengaruh terhadap produk tersebut. Salah satu faktor yang bisa mempengaruhi umur simpan suatu produk antara lain suhu. Penentuan umur simpan dengan faktor pembatas suhu dapat dilakukan dengan pendekatan kinetika kemunduran mutu Arrhenius.Dalam model ini sebagian besar kemunduran mutu bahan makanan termasuk reaksi orde nol dan orde satu. Dengan evaluasi constant rate $(\mathrm{k})$ pada tiga suhu atau lebih yang berbeda dapat dibuat grafik hubungan Arrhenius, yaitu ekstrapolasi dengan garis lurus hubungan antara In $\mathrm{k}$ dengan $1 / \mathrm{T}$ untuk memprediksi kecepatan reaksi (k) dari reaksi-reaksi dari suhu lain (Labuza, 1982). Tujuan penelitian ini yaitu untuk mengetahui suhu dan waktu sterilisasi yang terbaik, angka kecukupan panas sterilisasi (Nilai $F o$ ) serta melakukan pendugaan umur simpan terhadap nasi goreng dalam kemasan retort pouch.

\section{METODE PENELITIAN}

\section{Bahan}

Daging ayam kampung, bawang merah, bawang putih, garam, kecap manis, margarine, nasi putih, sosis sapi dari Pasar Wonosari Gunungkidul. Bahan kimia dan mikrobiologi untuk analisa yaitu : thiobar bituric acid (TBA), alkohol 96\%, aquades steril, dan plate count agar (PCA) dari supplier bahan kimia Yogyakarta. Kemasan retort pouch yang digunakan ukuran $20 \times 15 \mathrm{~cm}$ tebal 160 mikron terdiri dari lapisan nylon alumunium foil dan LLDPE. 
Alat

Alat yang digunakan dalam penelitian ini yaitu: Autoclave Tomy SS 325, timbangan teknis digital, Vacuum sealerDZ 400, kompor gas, Fo meter Ellab TMP 248129-1 series number 280235 dan 280240, Blender Philip HR 2115, bunsen, cawan petri, hot plate, labu erlenmeyer, inkubator Binder, laminar flow JSCB 1200SB, mikropipet, pH meter Eutech PC 700, tabung reaksi, dan vortex VM 300.

\section{Pembuatan Nasi Goreng}

Proses pembuatan nasi goreng diawali dengan menghaluskan bawang merah dan bawang putih sebagai bumbu. Setelah halus, kemudian margarin dipanaskan diatas wajan hingga meleleh dan kemudian bumbu halus dimasukkan. Bumbu halus ditumis hingga harum dan kering kemudian nasi putih dimasukkan bersama dengan garam dan kecap manis. Nasi putih digoreng hingga bercampur merata dengan semua bumbu.

NGo = Nasi goreng segar

$\mathrm{NG}_{1}=$ Nasi goreng retort pouch Sterilisasi $110^{\circ} \mathrm{C}, 15$ menit

$\mathrm{NG}_{2}=$ Nasi goreng retort pouch Sterilisasi $110^{\circ} \mathrm{C}, 20$ menit

$\mathrm{NG}_{3}=$ Nasi goreng retort pouch Sterilisasi $121^{\circ} \mathrm{C}, 15$ menit

$\mathrm{NG}_{4}=$ Nasi goreng retort pouch Sterilisasi $121^{\circ} \mathrm{C}, 20$ menit

\section{Sterilisasi Nasi Goreng Kemasan Retort Pouch}

Pada perlakuan proses sterilisasi diawali dengan menimbang nasi goreng sebanyak 126 gr, sosis sapi $27 \mathrm{gr}$, dan ayam suwir $27 \mathrm{gr}$ sehingga berat total $180 \mathrm{gr}$ dimasukan pada kemasan retort pouch (Kurniadi dkk, 2016). Kemasan retort pouch kemudian di vacuum sealer dengan kondisi vacuum selama 30 detik, flashing 2,5 detik, dan sealing 3 detik. Nasi goreng dalam kemasan retort pouch disterilisasi sesuai dengan perlakuan suhu dan lama sterilisasi yaitu $\mathrm{T} 1$ (suhu $\left.110^{\circ} \mathrm{C}, \mathrm{P}: 1 \mathrm{kgf} / \mathrm{cm}^{2}\right)$ dan $\mathrm{T} 2\left(121^{\circ} \mathrm{C}, \mathrm{P}: 1,5 \mathrm{kgf} / \mathrm{cm}^{2}\right)$ selama t1 (15 menit) dan t2 (20 menit). Untuk nasi goreng dalam kemasan retort pouch yang akan dianalisa nilai letalitas, didalam kemasan nasi goreng disisipkan sensor temperature dan diletakkan di tengah kemasan pouch. Setelah proses sterilisasi selesai, sampel dianalisa nilai letalitas, mikrobiologi, dan $\mathrm{pH}$. Sampel untuk pengujian pendugaan daya simpan disimpan selama 35 hari pada suhu $27^{\circ} \mathrm{C}, 35^{\circ} \mathrm{C}$, dan $55^{\circ} \mathrm{C}$.

\section{Uji Angka Kecukupan Panas (Fo)}

Uji Angka Kecukupan Panas atau nilai letalitas (Fo) menggunakan sensor suhu Ellab TMP 248129-1. Penelitian ini menggunakan dua sensor dimana satu sensor digunakan untuk mengukur suhu produk dan sensor yang lain digunakan untuk mengukur suhu autoclave. Sebelum dimasukkan ke dalam retort pouch, sensor diset up terlebih dahulu dengan menggunakan software Valsuite. Gambar reader pada program akan menjadi hijau yang menunjukkan bahwa sensor telah terbaca. Setelah muncul jendela Read Loggerkemudian pilih read dan akan muncul grafik yang menunjukkan nilai letalitas produk selama sterilisasi.

\section{Pengujian Mikrobiologi dengan Metode Penentuan Angka Lempeng Total (ALT)}

Pengujian nilai mikrobiologi diawali dengan menghaluskan nasi goreng dalam blender yang sudah disterilisasi. Sebanyak $1 \mathrm{ml}$ sampel kemudian dipindah secara aseptis ke $9 \mathrm{ml}$ aquades steril (pengenceran $10^{2}$ ) dan langkah ini diulang hingga didapat pengenceran $10^{4}$. Sebanyak $1 \mathrm{ml}$ sampel dari setiap pegenceran diinokulasi secara aseptis ke cawan petri dan dibuat duplo, kemudian diinkubasi pada inkubator suhu $37^{\circ} \mathrm{C}$ selama 48 jam dan dihitung koloni yang terbentuk. Rentang koloni yang digunakan mengacu pada standar Food Drug Administration (FDA) Bacteriological Analytical Manual (BAM) yaitu 25-250 koloni untuk setiap cawan petri (Sutton, 2012). 


\section{Pengujian pH}

10 gram sampel dalam $100 \mathrm{ml}$ aquades steril disaring dengan menggunakan kertas saring dan diletakkan dalam labu erlenmeyer. Kemudian diukur nilai pHnya dengan menggunakan pH meter Eutech 700 (Yuswita dkk., 2014).

\section{Uji sensoris}

Pada uji sensoris ini dilakukan oleh 30 orang panelis kategori tidak terlatih. Para panelis diminta mencicipi nasi goreng dalam kemasan retort pouch dan memberikan penilaian terhadap karakteristik rasa, aroma, bau, tekstur dan kesukaan produk secara keseluruhan. Tingkat persepsi panelis digambarkan berdasarkan score kesukaan sebagai berikut : 1 : sangat tidak suka 2 : suka 3 : netral 4 : agak suka 5 : sangat suka (Setyaningsih.D. et al. 2010)

\section{Pendugaan umur simpan menggunakan teknik Accelerated Shelf-life Test (ASLT) model Arrhenius}

Sampel disimpan selama 35 hari pada suhu $27^{\circ} \mathrm{C}, 35^{\circ} \mathrm{C}$, dan $55^{\circ} \mathrm{C}$ setiap selang 7 hari diuji nilai ketengikannya. Data dari nilai ketengikan diplot ke grafik hubungan waktu ( $x$ axis) dan suhu penyimpanan ( $y$ ordinat). Penentuan umur simpan ditentukan oleh $\mathrm{R}^{2}$ terbesar pada grafik nilai ketengikan .

Proses kemunduran mutu bahan makanan dapat dinyatakan dengan persamaan umum berikut (Fu and Labuza,1997; Labuza dan Riboh,1982):

$$
\frac{d Q}{d t}=k \cdot Q^{n}
$$

\section{Dimana :}

$Q \quad=$ faktor mutu yang diukur

$t \quad=$ waktu

$k \quad=$ ketetapan yang tergantung pada suhu dan Aw

$n=$ faktor pangkat atau orde reaksi

$d Q / d t=$ kecepatan perubahan dari faktor $\mathrm{Q}$ per satuan waktu (tanda positif jika kemundurannya dinyatakan dalam bertambahnya $Q$ dan negatif jika yang diukur adalah berkurangnya Q).

Reaksi kemunduran mutu orde nol dapat dinyatakan dengan persamaan (Brando and Silvaa, 2011) :

$$
t=\frac{\left(A_{0}-\mathrm{A}\right)}{\mathrm{k}}
$$

Dan untuk orde 1 reaksi kemunduran dapat dinyatakan dengan persamaan berikut :

$$
t=\frac{\ln \left(\frac{A_{0}}{A}\right)}{\mathrm{k}}
$$

\section{Dimana:}

$$
\begin{array}{ll}
\mathrm{A} & =\text { skor akhir } \\
\mathrm{A}_{0} & =\text { skor awal (hari ke-0) } \\
\mathrm{k} & =\text { Konstanta kecepatan reaksi } \\
\mathrm{t} & =\text { waktu penyimpanan (dalam hari, bulan atau tahun) }
\end{array}
$$




\section{Analisis TBA}

Analisis TBA dilakukan setiap selang 7 hari pada kurun waktu 35 hari. $10 \mathrm{~g}$ sampel dan $50 \mathrm{ml}$ aquades dicampur kedalam blender kemudian pindahkan ke tabung destilasi $1000 \mathrm{ml}$ dengan tambahan $47.5 \mathrm{ml}$ aquades dan $2.5 \mathrm{ml} \mathrm{HCL} \mathrm{4M}$. Setelah itu panaskan tabung destilasi sampai terkumpul $50 \mathrm{ml}$ destilat. Saring dan tuangkan ke Erlenmeyer lalu tambahkan reagen TBA $5 \mathrm{ml}$ (0.02M larutan asam thio barbituric dan $90 \%$ asam asetat glasial). Tahap selanjutnya panaskan pada air mendidih selama 35 menit dan dinginkan menggunakan air mengalir. Absorbansi diukur menggunakan panjang gelombang 528 nm (Devasagayam, et.all., 2003).

\section{HASIL DAN PEMBAHASAN}

\section{Pengaruh Suhu dan Waktu Sterilisasi Terhadap Nilai Letalitas ( $\left.\mathbf{F}_{\mathbf{0}}\right)$}

Patogen resisten yang dapat bertahan dalam kemasan pouch pada makanan rendah asam adalah Clostridium botulinum. Bakteri ini dapat membentuk spora tahan panas di bawah kondisi kurang menguntungkan, bakteri ini dapat tumbuh pada kondisi tanpa oksigen, tumbuh baik pada makanan dengan $\mathrm{pH}$ di atas 4,6 dan memproduksi racun yang dapat menyebabkan botulism dan dapat menyebabkan kematian pada hari ke tujuh (Holdswort and Simpson, 2007). Nilai letalitas standar untuk mengurangi jumlah $C$. botulinum dengan $D$ value 0,21 menit dan $Z$ value $10^{\circ} \mathrm{C}$ ialah sebesar 2,52 menit (Sun, 2006). Kurva kenaikan suhu selama proses sterilisasi disajikan dalam gambar 1 dan 2.

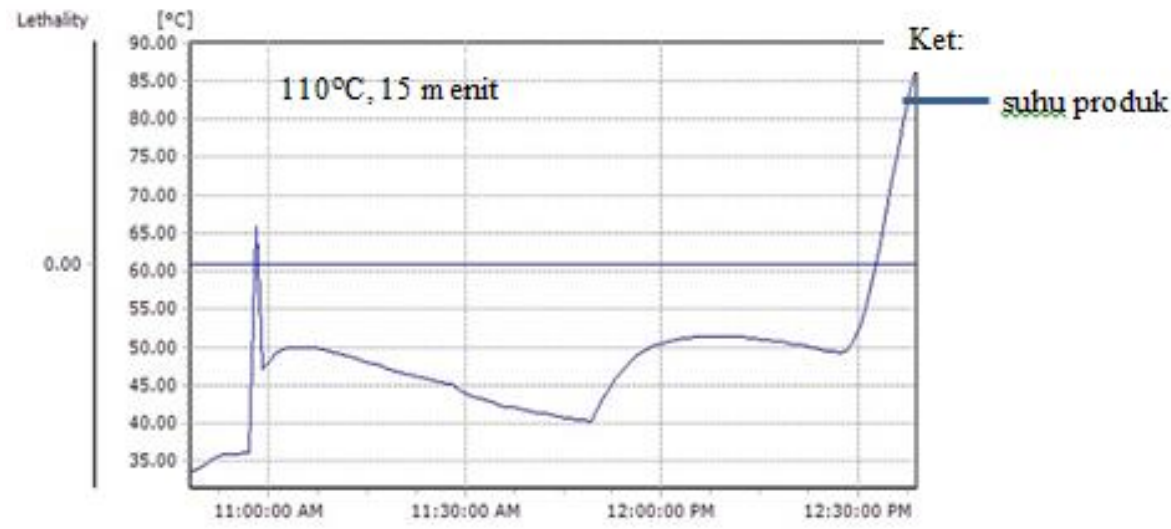

(A)

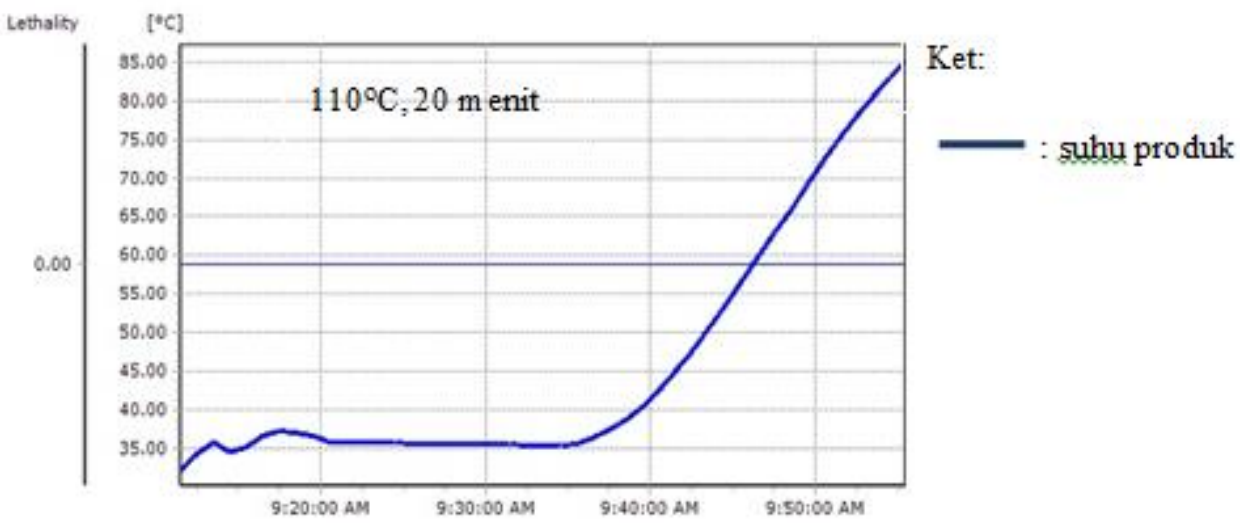

(B)

Gambar 1. Nilai Letalitas Produk Nasi Goreng Kemasan Pouch pada Sterilisasi (A) Suhu $110^{\circ} \mathrm{C}, 15$ menit (B) Suhu $110^{\circ} \mathrm{C}, 20$ menit 


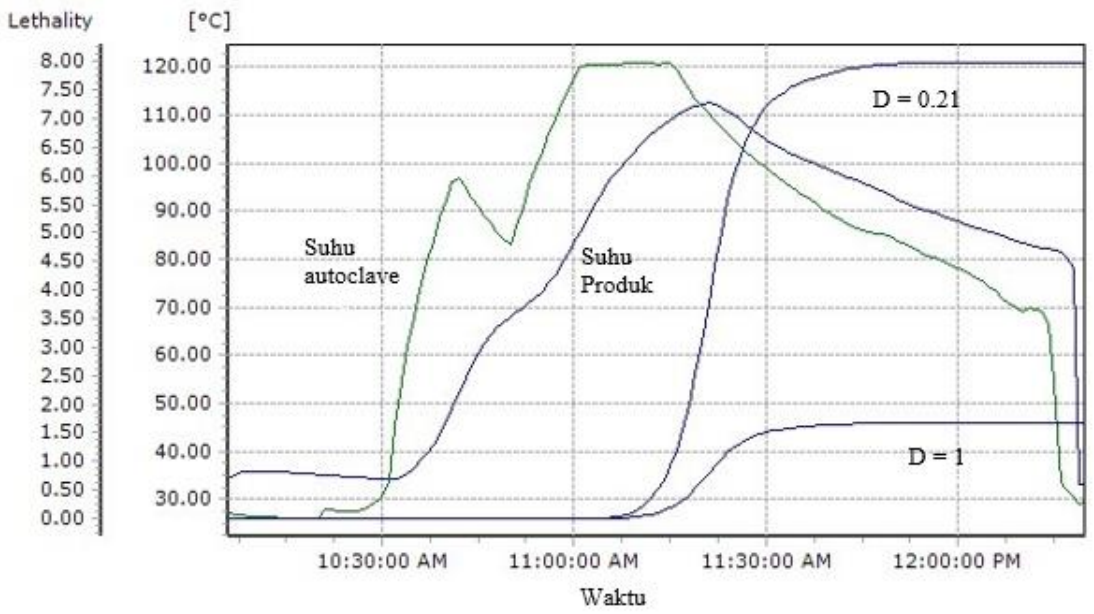

(A)

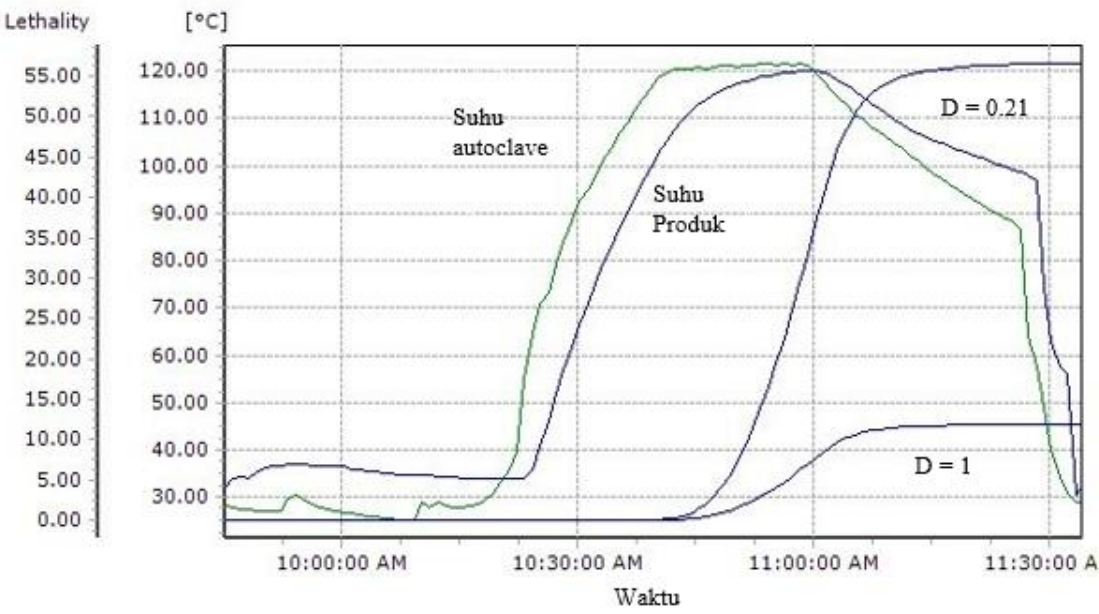

(B)

Gambar 2. Nilai Letalitas Produk Nasi Goreng Kemasan Pouch pada Sterilisasi (A) Suhu $121^{\circ} \mathrm{C}, 15$ menit (B) Suhu $121^{\circ} \mathrm{C}, 20$ menit

Pada penentuan nilai letalitas, suhu yang digunakan ialah $110^{\circ} \mathrm{C}$ dan $121^{\circ} \mathrm{C}$ dengan lama waktu sterilisasi 15 dan 20 menit. Suhu autoclave akan meningkat sejalan dengan waktu proses. Autoclave membutuhkan waktu \pm 25 menit untuk mencapai suhu sterilisasi $110^{\circ} \mathrm{C}$ dan $\pm 30-40$ menit untuk suhu $121^{\circ} \mathrm{C}$. Hasil penentuan nilai letalitas disajikan dalam Tabel 1.

Tabel 1. Nilai Letalitas Nasi Goreng Retort Pouch pada Beberapa Suhu dan Waktu Sterilisasi

\begin{tabular}{lcccc}
\hline \multicolumn{1}{c}{ Parameter } & $\mathbf{N G}_{\mathbf{1}}$ & $\mathbf{N G}_{\mathbf{2}}$ & $\mathbf{N G}_{\mathbf{3}}$ & $\mathbf{N G}_{\mathbf{4}}$ \\
\hline $\mathrm{Z}$ value $\left({ }^{\circ} \mathrm{C}\right)$ & 10 & 10 & 10 & 10 \\
$\mathrm{~F}_{0}$ value (menit) & 0 & 0 & 1.68 & 11.88 \\
\hline
\end{tabular}

Decimal Reduction Time (D value) merupakan waktu yang dibutuhkan untuk mengurangi populasi mikroba sebesar $90 \%$ atau 1 siklus logaritma pada suhu tertentu. Pada penelitian ini, nilai D value yang digunakan mengacu pada Sun (2006) sebesar 0,21 menit yang artinya untuk menurunkan jumlah $C$. botulinum sebesar $90 \%$ atau 1 siklus logaritma memerlukan waktu 0,21 menit. Semakin besar D value menunjukkan bahwa ketahanan panas mikroba tersebut juga semakin besar (Yuswita, 2014). Temperature coefficient of microbial destruction (Z Value) adalah suhu yang dibutuhkan untuk mengurangi nilai $D$ value sebesar $90 \%$ atau 1 
logaritma. Z value yang digunakan pada penentuan sebesar $10^{\circ} \mathrm{C}$ (Sun, 2006; Holdsworth dan Simpson, 2007) yang artinya untuk mempercepat proses inaktivasi $C$. botulinum menjadi 0,021 menit pada suhu sterilisasi harus dinaikkan sebesar $10^{\circ} \mathrm{C}$.

Sterilization Process Equivalent Time (F value) atau nilai letalitas adalah waktu yang dibutuhkan untuk membunuh mikroba target hingga mencapai level tertentu pada suhu tertentu (Sun, 2006). Proses termal untuk makanan rendah asam setidaknya harus mampu mengurangi populasi mikroba minimal sebesar 12 siklus logaritma atau 12D (Sun, 2006). Sehingga nilai letalitas standar yang digunakan penelitian ini sebesar 2,52 menit.

Berdasarkan hasil penelitian didapatkan nilai letalitas untuk suhu $110^{\circ} \mathrm{C}$ pada sterilisasi selama 15 dan 20 menit masih menunjukkan nilai 0 . Hal ini menunjukkan bahwa pada suhu $110^{\circ} \mathrm{C}$ belum mampu untuk membunuh spora $C$. Botulinum. Menurut Ray (2004), Clostridium botulinum merupakan bakteri tahan panas yang terdapat dalam produk yang dikalengkan dan masih dapat tumbuh pada suhu dibawah $120^{\circ} \mathrm{C}$.

Pada suhu $121^{\circ} \mathrm{C}$, nilai letalitas yang didapat untuk sterilisasi selama 15 dan 20 menit secara berturut-turut adalah 1,68 dan 11,88 menit. Apabila dibandingkan dengan nilai letalitas standar $C$. botulinum sebesar 2,52 menit, maka nilai letalitas yang didapat pada sterilisasi $121^{\circ} \mathrm{C}$ selama 15 menit lebih kecil daripada nilai letalitas standar. Sehingga dapat dikatakan bahwa sterilisasi suhu $121^{\circ} \mathrm{C}$ selama 15 menit belum cukup untuk menginaktivasi $C$. botulinum. Pada sterilisasi suhu $121^{\circ} \mathrm{C}$ selama 20 menit, nilai letalitas yang didapat lebih besar daripada letalitas standar. Sehingga, dapat dikatakan proses termal suhu sterilisasi $121^{\circ} \mathrm{C}$ selama 20 menit sudah mencukupi untuk menginaktivasi $C$. botulinum (Holdsworth and Simpson, 2007). Sterilisasi pada suhu $121^{\circ} \mathrm{C}$ selama 20 menit merupakan proses sterilisasi nasi goreng dalam kemasan pouch yang optimal. Hal ini berdasarkan pada penelitian mengenai nilai letalitas produk rendah asam lainnya.

Nilai letalitas yang didapat pada penelitian telur dalam kemasan retort pouch sebesar 7,46-7,77 menit dengan kondisi operasi suhu $100-121^{\circ} \mathrm{C}$ dan kisaran tekanan 5 sampai 15 lbs gauge(Kumar et al., 2015), Fo = 8-12 menit dengan kondisi operasi suhu $121{ }^{\circ} \mathrm{C}$ untuk produk daging (Ranggana, 2000). Berdasarkan beberapa rentang nilai letalitas makanan dalam kemasan retort pouch yang didapat dalam penelitian sebelumnya, maka sterilisasi dengan suhu $121^{\circ} \mathrm{C}$ selama 20 menit merupakan proses termal yang mencukupi untuk menginaktivasi C. botulinum.

\section{Pengaruh Suhu dan Waktu Sterilisasi Terhadap Nilai Mikrobiologi}

Hasil perhitungan nilai mikrobiologi dengan Angka lempeng Total (ALT) dan pengukuran pH disajikan dalam tabel 2

Tabel 2. Hasil Pengujian Nilai Mikobiologi dan pH Nasi Goreng Kemasan Retort Pouch

\begin{tabular}{ccc}
\hline Sampel & ALT $\left(\mathbf{1 0}^{\mathbf{3}} \mathbf{c f u} / \mathbf{m l}\right)$ & $\mathbf{p H}$ \\
\hline $\mathrm{NGo}_{\mathrm{NG}}$ & 5,6 & 6,13 \\
$\mathrm{NG}_{2}$ & 2,5 & 6 \\
$\mathrm{NG}_{3}$ & 1,4 & 6,37 \\
$\mathrm{NG}_{4}$ & 0,8 & 6,41 \\
\hline
\end{tabular}

Pengujian ALT dimaksudkan untuk mengetahui jumlah mikroba yang terdapat dalam suatu produk dengan cara menghitung koloni bakteri yang tumbuh pada media agar (Yunita dkk., 2015). Berdasarkan hasil perhitungan mikroorganisme, sampel yang mengandung mikroba terbanyak adalah sampel nasi goreng segar yaitu 5,6x $10^{3} \mathrm{cfu} / \mathrm{ml}$ dan sampel dengan jumlah mikroba paling sedikit adalah sampel nasi goreng yang di sterilisasi pada suhu $121^{\circ} \mathrm{C}$ selama 20 menit yaitu $0,4 \times 10^{3} \mathrm{cfu} / \mathrm{ml}$. Salah satu tujuan sterilisasi komersil adalah mencegah 
pertumbuhan mikroba sehingga produk tetap aman selama penyimpanan (Coles et al., 2003). Karena adanya panas dari autovclave menyebabkan terjadinya koagulasi protein essensial. Ketika panas digunakan sebagai agen sterilisasi, akan terjadi pembelahan ikatan hidrogen intramolekul antara protein pada sel mikroba. Hal ini menyebabkan kerusakan permanen semua fungsi metabolisme organisme (Oyawale and Olaoye, 2007).

Menurut International Commission for Microbiological Specification for Foods (ICMSF), standar totalplate count untuk makanan ready to eat dibagi menjadi 3, yaitu dapat diterima $\left(0-10^{3}\right)$, dapat ditoleransi $\left(10^{4} \leq 10^{5}\right)$, dan tidak dapat diterima $\left(10^{6}\right)$ (ICMSF dalam Monday et al., 2014). Sedangkan menurut Food Safety Institute of Ireland, jumlah koloni bakteri yang dapat dihitung pada nasi ready to eat maksimal sebesar $10^{5}$ (Wogu et al., 2011). Semua sampel nasi goreng menunjukkan nilai dapat diterima $\left(0-10^{3}\right)$ sehingga dapat disimpulkan bahwa nasi goreng dalam kemasan retort pouch aman untuk dikonsumsi. Nasi goreng dalam retort pouch ini masih tergolong aman untuk dikonsumsi. Hal tersebut berarti proses yang dilakukan selama memproduksi nasi goreng dalam retort pouch sudah termasuk pengolahan yang baik dan benar. Derajat keasamaan $(\mathrm{pH})$ merupakan skala yang digunakan untuk menunjukkan keasamaan atau kebasaan. Rentang skala $\mathrm{pH}$ adalah 1-14. Pada rentang 1-6 bersifat asam, 7 bersifat netral, dan 8-14 bersifat basa. pH dapat ditentukan dengan menggunakan kertas lakmus dan dapat juga menggunakan $\mathrm{pH}$ meter untuk mendapatkan keakuratan yang lebih besar. pH tidak menentukan kandungan asam dalam makanan (UNIDO, 2004).

Nasi mempunyai kisaran pH 6,00-6,70 (FDA, 2007) sehingga nasi termasuk dalam makanan rendah asam (ICMSF, 1988 dalam Forsythe, 2000). Makanan yang mempunyai pH di atas 4,6 sangat rawan untuk pertumbuhan $C$. botulinum. Pada penelitian yang telah dilakukan, nilai pH sampel sebagian besar menunjukkan peningkatan dibanding sampel segar. Peningkatan $\mathrm{pH}$ ini dapat terjadi karena ikatan hidrogen produk akan merenggang selama pemanasan. Sehingga muatan positif produk akan bertambah (Rajkumar et al., 2010).

Adanya penurunan $\mathrm{pH}$ pada sampel nasi goreng sterilisasi suhu $110^{\circ} \mathrm{C}$ selama 15 menit dapat terjadi karena adanya degradasi pati. Penurunan nilai $\mathrm{pH}$ juga disebabkan oleh terbentuknya asam karena adanya reaksi spontan antara $\mathrm{CO}_{2}$ dengan $\mathrm{H}_{2} \mathrm{O}$. Gas $\mathrm{CO}_{2}$ terbentuk karena penguraian karbohidrat menjadi unit-unit yang lebih sederhana karena aktivitas mikroba dalam proses fermentasi (Farikha dkk., 2013). Selain itu, penurunan pH dapat terjadi karena adanya degradasi protein dan pelepasan asam amino bebas (Rajan et al., 2011).

\section{Hasil Uji sensoris}

Pengujian sensoris dilakukan terhadap 4 produk nasi goreng retort pouch masing-masing sterilisasi. Adapun parameter pengujian meliputi warna, aroma, rasa, tekstur, dan kesukaan secara keseluruhan. Pengujian sensoris dilakukan terhadap 30 panelis tidak terlatih. Hasil pengujian sensoris dapat dilihat pada tabel 3 .

Tabel 3. Hasil Uji Sensoris Nasi Goreng dalam Kemasan Retort Pouch

\begin{tabular}{cccccc}
\hline Sampel & Warna & Aroma & Rasa & Tekstur & $\begin{array}{c}\text { Kesukaan } \\
\text { Keseluruhan }\end{array}$ \\
\hline $\mathrm{NG}_{1}$ & $3,41^{\mathrm{a}}$ & $3,34^{\mathrm{a}}$ & $2,84^{\mathrm{a}}$ & $2,66^{\mathrm{a}}$ & $2,97^{\mathrm{a}}$ \\
\hline $\mathrm{NG}_{2}$ & $3,75^{\mathrm{a}}$ & $3,66^{\mathrm{a}}$ & $3,69^{\mathrm{b}}$ & $3,31^{\mathrm{b}}$ & $3,62^{\mathrm{b}}$ \\
\hline $\mathrm{NG}_{3}$ & $3,56^{\mathrm{a}}$ & $3,69^{\mathrm{a}}$ & $3,97^{\mathrm{b}}$ & $3,84^{\mathrm{c}}$ & $3,78^{\mathrm{c}}$ \\
\hline $\mathrm{NG}_{4}$ & $3,57^{\mathrm{a}}$ & $3,79^{\mathrm{a}}$ & $3,96^{\mathrm{b}}$ & $3,84^{\mathrm{c}}$ & $3,80^{\mathrm{c}}$ \\
\hline
\end{tabular}

Keterangan : Huruf yang sama pada kolom yang sama menunjukkan tidak adanya perbedaan yang nyata pada taraf $a=5 \%$

Skala penilaian : $1=$ sangat tidak suka; 2 = tidak suka; $3=$ netral; $4=$ suka ; $5=$ sangat suka 
Berdasarkan Tabel 3, hasil pengujian sensoris menunjukkan bahwa keempat produk nasi goreng dalam retort pouch diterima dan disukai para panelis. Dari 4 produk nasi goreng retort pouch, terlihat bahwa secara keseluruhan produk yang paling disukai adalah $\mathrm{NG}_{4}\left(121^{\circ} \mathrm{C}, 20\right.$

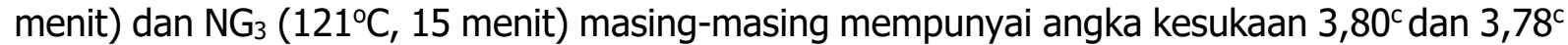
yang secara statistik tidak berbeda nyata. Namun pada sterilisasi suhu $121^{\circ} \mathrm{C}$ selama 20 menit, nilai letalitas ( $F o$ yyang didapat lebih besar dari pada letalitas standar $(F O=3)$ dan lebih baik dari $121^{\circ} \mathrm{C}$ selama 20 menit. Fo pada $\mathrm{NG}_{4}$ dan $\mathrm{NG}_{3}$ masing-masing yaitu 11.88 dan 1,68.Sehingga, dapat dikatakan proses termal suhu sterilisasi $121^{\circ} \mathrm{C}$ selama 20 menit memenuhi angka kecukupan panas sterilisasi dan sudah mencukupi untuk menginaktivasi C. botulinum (Holdsworth and Simpson, 2007). Sterilisasi pada suhu $121^{\circ} \mathrm{C}$ selama 20 menit merupakan proses sterilisasi nasi goreng dalam kemasan retort pouch yang optimal. Produk terpilih ini kemudian dilakukan pengujian pendugaan umur simpan seperti dapat dilihat pada tabel 4 dan 5 dan gambar 3 dan 4 dibawah ini.

\section{Pendugaan Umur Simpan}

Nilai TBA meningkat dengan meningkatnya suhu dan waktu, yang disebabkan oleh oksidasi lemak pada produk pangan (Sainsbury et all.2016). Nilai kritis TBA yaitu $0.5 \mathrm{mg} / \mathrm{kg}$ berdasar pada penelitian terdahulu. Hasil uji TBA setiap minggu pada suhu yang berbeda disajikan pada tabel 4

Tabel 4. Nilai TBA Nasi Goreng

\begin{tabular}{cccc}
\hline \multirow{2}{*}{ MINGGU KE } & \multicolumn{3}{c}{ NIlai TBA } \\
\cline { 2 - 4 } & $\mathbf{2 7}$ & $\mathbf{3 5}$ & $\mathbf{5 5}$ \\
\hline 0 & 0.0630 & 0.0630 & 0.0630 \\
1 & 0,0653 & 0,0665 & 0,0681 \\
2 & 0,0708 & 0,0718 & 0,0720 \\
3 & 0,0909 & 0,1016 & 0,1027 \\
4 & 0,1123 & 0,1162 & 0,1178 \\
5 & 0,1241 & 0,1267 & 0,1280 \\
\hline
\end{tabular}

Pemilihan order berdasar nilai $\left(\mathrm{R}^{2}\right)$ terbesar pada order 0 dan 1 . Pemilihan orde reaksi peningkatan ketengikan nasi goreng dalam retort pouch dilakukan dengan cara membandingkan koefisien determinasi $\left(R^{2}\right)$ tiap persamaan regresi linier pada suhu yang sama dari reaksi orde nol dengan reaksi orde satu. Orde reaksi dengan nilai koefisien determinasi paling besar merupakan orde reaksi yang digunakan.

Grafik hubungan nilai TBA pada Order 0 dan Order 1 disajikan pada Gambar 3.

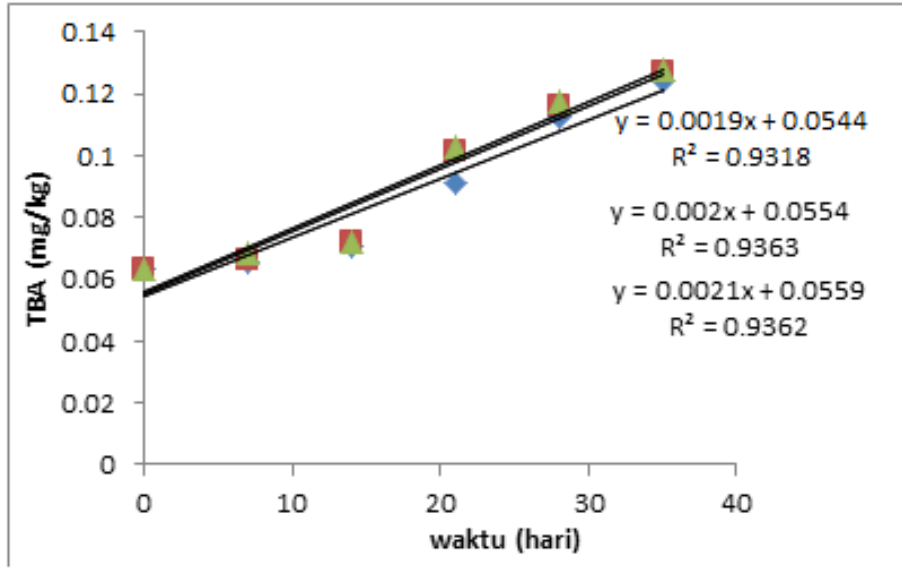

(a) 


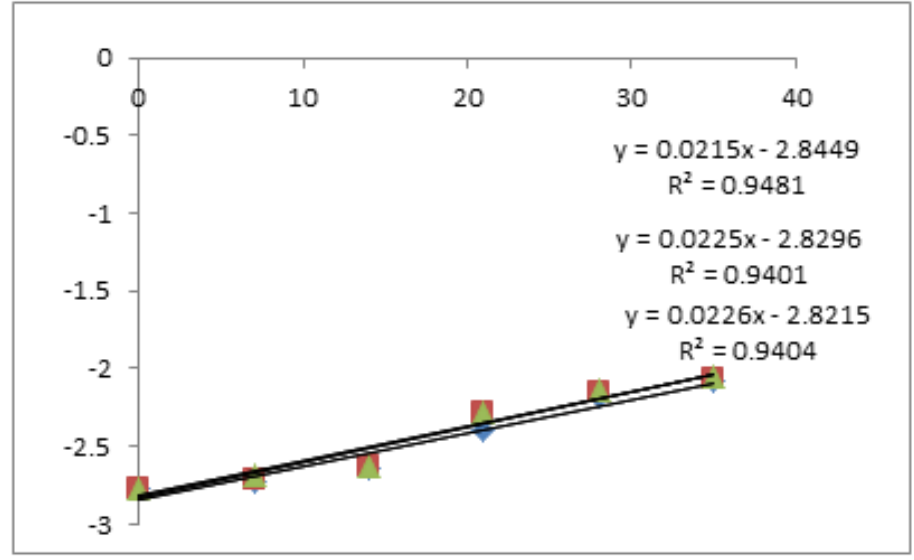

(b)

Gambar 3. Grafik hubungan nilai TBA pada (a) Order 0 TBA, (b) Order 1 TBA

Berdasarkan Gambar 3 dapat diketahui persamaan regresi linear, seperti yang disajikan pada Tabel 5

Tabel 5. Persamaan Regresi Linier Nilai TBA

\begin{tabular}{ccccc}
\hline \multirow{2}{*}{ Suhu ( C ) } & \multicolumn{2}{c}{ Persamaan Regresi Linier } & \multicolumn{2}{c}{$\mathrm{R}^{2}$} \\
\cline { 2 - 5 } & Orde nol & Orde Satu & Orde Nol & Orde Satu \\
\hline 27 & $\mathrm{Y}=0,0019 \mathrm{x}+0,0544$ & $\mathrm{Y}=0,0215 \mathrm{x}-0,9481$ & 0,9318 & 0,9481 \\
\hline 35 & $\mathrm{Y}=0,0020 \mathrm{x}+0,0054$ & $\mathrm{Y}=0,0225 \mathrm{x}-2,8296$ & 0,9363 & 0,9401 \\
\hline 55 & $\mathrm{Y}=0,0021 \mathrm{x}+0,0559$ & $\mathrm{Y}=0,01226 \mathrm{x}-2,82155$ & 0,9362 & 0,9404 \\
\hline
\end{tabular}

Tabel 5 menunjukkan bahwa nilai $\mathrm{R}^{2}$ orde satu pada suhu $27^{\circ} \mathrm{C}$ lebih besar dibandingkan orde nol, sehingga dipilih orde satu untuk ditentukan persamaan Arrhenius. Penentuan persamaan Arrhenius dilakukan dengan membuat plot nilai In $\mathrm{k}$ dan $1 / \mathrm{T}$ pada reaksi perubahan nilai TBA nasi goreng dalam retort pouch. Plot Arrhenius disajikan pada gambar 4.

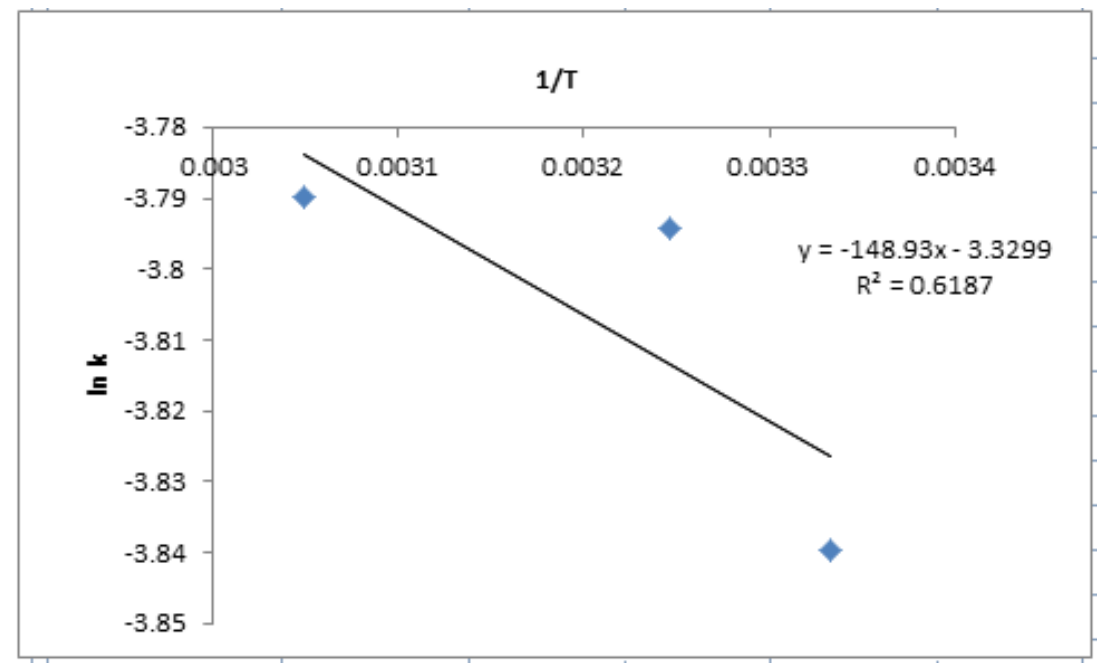

Gambar 4. Plot Arrhenius

Penentuan persamaan Arrhenius dilakukan dengan plot In $\mathrm{k}$ dan $1 / \mathrm{T}$ :

Persamaan: $y=-148.93 x-3.3299$ 
Ekstrapolasi pada suhu normal $30^{\circ} \mathrm{C}(303 \mathrm{~K})$ menghasilkan:

$$
\begin{aligned}
& \text { In } k=148.93(1 / T)-3.3299 \\
& \ln k_{(303)}=-3.3299 \\
& k_{(303)}=0.0358
\end{aligned}
$$

Berdasarkaan penelitian sebelumnya nilai kritis TBA yaitu $0.5 \mathrm{mg} / \mathrm{kg}$; initial TBA (Ao) $0.0630 \mathrm{mg} / \mathrm{kg}$, sehingga umur simpan yaitu:

$$
\begin{aligned}
\text { umur simpan }= & \frac{\ln \frac{A 1}{A O}}{k} \\
& =\frac{\ln \frac{0.063}{0.5}}{0.0358} \\
& =247.78 \text { hari }
\end{aligned}
$$

Prediksi umur simpan nasi goreng dalam kemasan retort pouch yaitu 247.78 hari atau 8.25 bulan. Menurut Varalakshmi et al.,(2014) produk makanan dalam kemasan retort pouch dapat disimpan pada suhu kamar dengan umur simpan 18 bulan tanpa perlu ditambahkan zat pengawet.

\section{KESIMPULAN}

Suhu sterilisasi optimal pada nasi goreng kemasan retort pouch yaitu $121^{\circ} \mathrm{C}$ selama 20 menit dengan nilai sterilitas (Fo) 11,88 menit, ALT 0,4 $\times 10^{3} \mathrm{cfu} / \mathrm{ml}$ dan $\mathrm{pH} 6,38$. Prediksi umur simpan nasi goreng kemasan retort pouch menggunakan metode $A S L T$ persamaan Arrhenius pada suhu penyimpanan $30^{\circ} \mathrm{C}$ yaitu 247.78 hari atau 8.25 bulan.

\section{UCAPAN TERIMA KASIH}

Penelitian ini mendapat dukungan dana dari Kegiatan Unggulan LIPI 2017 untuk itu penulis mengucapkan terimakasih pada pimpinan LIPI, juga kepada Viviana Puji Rahayu.

\section{DAFTAR PUSTAKA}

Bindu, J., Srinivasa, G.T.K., Unnikrishnan, N.T.S. 2004. Ready-to-eat mussel meats processed in retort pouches for the retail and export market. Packaging Technology and Science. Volume 17. Number 3. May 2004.pp.113-117 (5). John Wiley and Sons. Ltd.

Brandão, T.R.Sand Silvaa, C.L.M. 2011. "Dynamic approach for a ssessing food quality and safety characteristics : the case of processed foods" Ital.Oral Surg., vol.1, pp.10151025.

Coles, Richard, derek McDowell, and Mark J. Kirwan. 2003. Food Packaging Technology. CRC Press. New York.

Devasagayam, T.P.A., Boloor, K. Kand Ramasarma, T. 2003 "Methods for estimating lipid peroxidation : Ananalysis of merits and demerits" vol.40, October, pp.300-308. 
Farikha, Ita Noor, Choirul Anam, dan Esti Widowati. 2013. Pengaruh Jenis Dan Konsentrasi Bahan Penstabil Alami terhadapkarakteristik Fisikokimia Sari Buah Naga Merah (Hylocereus Polyrhizus) Selama Penyimpanan. Jurnal Teknosains Pangan 2(1): 30-38.

Food Drug Administration (FDA). 2007. Approximate $\mathrm{pH}$ of Foods and Food Product. Department of Health and Human Service. Amerika Serikat.

Fu, B. and Labuza, T. P. 1997. "Shelf Life Testing: Procedures and Prediction Methods for Frozen Foods," University of Minnesota.

Hidayati, Ratna, dan Rita Ismawati. 2014. Peningkatan Kualitas Olahan Beras Sebagai Bahan Makanan Pokok Melalui Penambahan Daun Kelor. E-Journal Boga 03 (1): 205-211.

Holdsworth, Donald and Ricardo Simpson. 2007. Thermal Processing of Packaged Foods: Second Edition. Springer. Washington.

Kumar, R. Johnsy George, Dhananjay Kumar, Jayaprahash, C Nataraju, S Lakshmana, J H Kumaraswamy, M R Kathiravan, T Rajamanickam, R Madhukar, N, and Nadanasabapathi. 2015. Development and Evaluation of Egg Based Ready to Eat (RTE) Product in Flexible Retort Pouches. African Journal of Food Science 9 (24): 243-251.

Kurniadi, M, N Salam, A Kusumaningrum, A Nursiwi, M Angwar, A Susanto, A Nurhikmat, Triwiyono, and A Frediansyah. 2016. Shelf-life Prediction of Canned "Nasi Uduk" Using Accelerated Shelf-life Test (ASLT) Arrhenius Model. Prosiding International Conference on Engineering Science and Nanotechnology. Unpublished.

Lewis, Michael, and Neil Heppell. 2000. Continous Thermal Processing of Foods: Pasteurization and UHT Sterilization. Aspen Publishers. Maryland.

Lim, Seung Talk and Jung Ah Han. 2016. Improvement in Antioxidant Functionality and Shelf Life of Yukwa (fried Rice Snack) by Tumeric (Curcuma Langa L) Powder Addition. Food Chemistry 199: 590-596.

Monday, I E, Francis J I, and Mohammad S U. 2014. Microbiological Quality of Ready-To-Eat Foods (Rice and Moimoi) Sold By Food Vendors in Federal Polytechnic Bali, Taraba State Nigeia. IOSR Journal Of Environmental Science, Toxicology And Food Technology (IOSRJESTFT) 8 (2): 145-149.

Murniyati. 2009. Pengolahan Retort Pouch untuk Produk Pangan Siap Saji. Squalen 4(2): 5560.

Oyawale, F A, and A E Olaoye. 2007. Design and Construction of an Autoclave. The Pacific Journal of Science and Technology 8 (2): 224-230.

Rajan, S V, V Kulkarni, and V Chandirasekaran. 2011. Preparation and Storage Stability of Retort Processed Chettinad Chicken. J Food Sci Techno 51(1): 173-177.

Rajkumar, V, Dushyanthan K, and Arun K Das. 2010. Retort Pouh Processing of Chettinad Style Goat Meat Curry - A Heritage Meat Product. JFood Sci techno 47(4): 372-379.

Ranggana, S. 2000. Handbook of Canning and Aseptic Packaging. Tata McGraw-Hill Publishing Company Limited. New Delhi.

Ray, Bibek. 2004. Fundamental Food Microbiology. CRC Press. New York.

Sainsbury.J., Grypa.R., Ellingworth.J., Duodu.G., Kock .H.L.D. The Effects of Antioxidants and Shelf Life Conditions on Oxidation Markers in a Sunflower oil salad dressing emulsion (SOSDE). Food Chemistryolume 213. 15 December 2016.pp 230-237.

Shihab, Mohammedali, CP, Hafeeda P, Kumar R, Kathiravan, T and Nadanasabapathi S. 2013. Development and Evaluation of Shelf Stable Retort Processed Ready to Drink (RTD) Traditional Thari Kanchi Payasam in Flexible Retort Pouches. International Food Research Journal 20 (4): 1765-1770.

Sun, Da Wen. 2006. Thermal Food Processing: New Technologies and Quality Issues. Tayor and Francis Group. Boca Raton.

Sutton, Scott. 2012. The Limitations of CFU: Compliance to CGMP Requires Good Science. Journal of GXP Compllance 16 (1): 74-80. 
UNIDO. 2004. Small-scale Fruit and Vegetable Processing and Products.United Nations Industrial Development Organization. Vienna.

Wogu, M. D., Omoruyi, M. I, Odeh, H. O. and Guobadia, J. N. 2011. Microbial load in readyto-eat rice sold in Benin City. Journal of Microbiology and Antimicrobials 3 (2): 29-33.

Yunita, Merisa, Yusuf Hendrawan, dan Rini Yulianingsih. 2015. Analisa Kuantitatif Mikrobiologi pada Makanan Penerbangan (Aerofood ACS) Garuda Indonesia Berdasarkan TPC (Total Plate Count) dengan Metode Pour Plate. Jurnal Keteknikan Pertanian Tropis dan Biosistem 3(3): 237-248.

Yuswita, Elia. 2014. Optimasi Proses Termal untuk Membunuh Clostridium Botulinum. Jurnal Aplikasi Teknologi Pangan 3(3): 5-6.

Labuza,T.P and D. Riboh. 1982. Theory and Application of Arrhenius Kinetics to The Prediction of Nutrient Losses in Food. J. Food Technology. 66 - 74. 